\title{
Response of paddy field cyanobacterium, Westiellopsis prolifica Janet to the inorganic nitrogenous fertilizers
}

\author{
Mamiyil Shamina* \\ Cyanobacterial Diversity Division, Department of Botany, University of Calicut, Kerala- 673635, India
}

Received: August 16, 2020 Revised: February 06, 2021 Accepted: February 19, 2021 Published: March 30, 2021

*Corresponding Author: Mamiyil Shamina

E-mail: shaminaraj@yahoo.co.in KEYWORDS: Ammonium sulphate, cyanobacteria, urea, Westiellopsis prolifica

\begin{abstract}
Cyanobacteria are prokaryotic nitrogen fixing microorganism which played a significant role in the nitrogen fixation and contributed much to the submerged rice cropping system of the world. It can luxuriantly flourish in paddy fields and providing nitrogen as well as various growth promoting substances that influence the growth of paddy plants. India, being an important rice producing country of the world, depends upon various inorganic fertilizers for rice cultivation. The heterocystous cyanobacterium, Westiellopsis prolifca is a common inhabitant in most of the paddy fields of Kerala. The growth and other biochemical parameters upon the growth of cyanobacterium were assayed. The nitrogenous fertilizer ammonium sulphate influences the chlorophyll-a synthesis, protein content and growth rate. But the ammonia excretion was drastically reduced in cyanobacterial cultures upon the treatment with inorganic fertilizers.
\end{abstract}

\section{INTRODUCTION}

Cyanobacteria are oxygen evolving, nitrogen fixing prokaryotes occur in every conceivable habitats but abundantly in water logged rice fields in several rice growing countries. Nitrogen fixing cyanobacteria play a vital role in the maintanence of soil fertility and sustainability in rice field ecosystems (Roger \& Reynaud, 1979). Cyanobacterial inoculation to rice crop was found to be effective in different agroclimatic conditions like tropical or temperate climates and soil types such as saline soils, phosphorous rich soils, alkaline or acidic soils etc. (Singh et al., 2017). The paddy field ecosystem provides an environment favourable for the growth of cyanobacteria with respect to their requirement for light, water, temperature, humidity and nutrient availability. In submerged soil system, biological nitrogen fixation contributes 25 to $30 \mathrm{~kg}$ nitrogen per hectre for one cropping season (Saexena et al., 2007; Kaushik, 2001). They are cosmopolitan in distribution and occur in every conceivable habitat where life is possible. They are reported to occur in extreme climatic conditions such as hot springs, polar deserts and Antartic regions (Halder, 2015, 2016). Even though they are ubiquitious, they prefer to grow in rice fields because the soil $\mathrm{pH}$, temperature, humidity, crop canopy and soil moisture are favourable for its growth in paddy fields.
It releases a large number of secondary metabolites into the paddy fields which also influences the growth of paddy (Wilson, 2006). The beneficial effect of cyanobacterial biofertilizer for paddy such as increase in number of tillers, seeds, length of the plant and leaf, yield etc. has been well documented (Karthikeyan et al., 2009; Sao \& Samual, 2018; Radhakrishnan \& Venkitaraman, 2005). Cyanobacterial biomass is also used for the production of various bioactive compounds, food items and biofuels (Hall et al., 1995; Malik et al., 2001; Paumann et al., 2005). They can control the deficiency of nitrogen in the soil and also improves its properties. Apart from nitrogen fixation, it also influences the overall growth of paddy including the grain yield (Roger et al., 1980; Singh, 1981; Alam et al., 2014). Since the urea and ammonium sulphate are the easily available and commonly used inorganic nitrogen fertilizer in the paddy fields of India, this made the the author to study how much these synthetic nitrogen fertilizers such as urea and ammonium sulphate influences the growth of paddy field cyanobacterium, Westiellopsis prolifica.

\section{MATERIALS AND METHODS}

The cyanobacterium, Westiellopsis prolifica Janet was collected from the paddy fields of Kerala. The organism was made into

Copyright: (C) The authors. This article is open access and licensed under the terms of the Creative Commons Attribution License (http://creativecommons.org/licenses/by/4.0/) which permits unrestricted, use, distribution and reproduction in any medium, or format for any purpose, even commercially provided the work is properly cited. Attribution — You must give appropriate credit, provide a link to the license, and indicate if changes were made. 
unialgal culture by dilution culture followed by culturing in BG-11 nitrogen free medium (Rippka et al., 1979) containing $0.8 \%(\mathrm{w} / \mathrm{v})$ agar. Pure colonies were transferred to liquid medium and incubated. The cultures were maintained in culture racks at a temperature of $25 \pm 2{ }^{\circ} \mathrm{C}$ under continuous illumination of 1500-2000 lux for 12 hours light and 12 hours darkness. The growth was assayed in terms of chlorophyll-a. For this, the culture suspension of cyanobacterium was homogenized and centrifuged at $5000 \mathrm{rpm}$ for 10 minutes. The supernatant was discarded and the pellet was suspended in $80 \%$ acetone in dark refrigerator for 20-24 hours. The absorbance of the acetone extract was measured using a spectrophotometer. The proteins were estimated (Lowry et al., 1951) and for this the cyanobacterial pellet was suspended in $10 \%$ TCA. It was then treated with alkaline reagent and also with $1 \mathrm{~N}$ FolinCiocalteau reagent and incubated in dark for 30 minutes and the absorbance was measured at a wavelength of $750 \mathrm{~nm}$ using spectrophotometer. The release of ammonia was measured by phenol- hypochlorite method with a modification in $\mathrm{pH}$ of the reagent (Solorzano, 1969).

\section{RESULTS}

For studying the effect of inorganic nitrogen fertilizers such as urea and ammonium sulphate, the stock solutions were prepared in distilled water and aseptically added to the culture medium to obtain the concentrations of 1,5,10 and $20 \mathrm{ppm}$ respectively. Equal amount of exponentially growing cultures were inoculated into the medium and harvested after 28 days. W. Prolifica grown in ammonium sulphate showed better growth rate than the cultures grown in urea under all the concentrations such as 1 , 5,10 , and $20 \mathrm{ppm}$ measured at an absorbance of $760 \mathrm{~nm}$ after 28 days of inoculation. But the production of protein was almost same in both urea and ammonium sulphate grown cultures. The chlorophyll- content was higher in the cyanobacterial cultures grown in ammonium sulphate than that of grown under urea treated cultures. Ammonia excreation was more in control than in nitrogenous fertilizers treated samples. However, W. Prolifica could with stand more in urea than in ammonium sulphate in all the treated concentrations. The results are given in Table 1 and 2 .

\section{DISCUSSION}

The growth and abundance of cyanobacterial flora is chiefly influenced by the type and mode of application of inorganic fertilizers such as nitrogen, phosphorous and potassium (Kaushik, 1987). Among the various nutrients supplemented as fertilizers in the paddy fields, nitrogen plays an important role in sustaining crop productivity because it is an essential element required for the growth of paddy. According to the present study, the ammonia excretion was drastically reduced in cultures grown in nitrogen sources and it agrees with the findings of Anand and Parameswaran (1990). But enhancement of nitrogenase activity in the presence of exogenous ammonium source in Anabaena sp. has been reported (Bottomley \& Stewart, 1976). The cyanobacterium Cylindrospermum showed nitrogenase activity in presence of nitrogenous fertilizers (Anand, 1990).
However, the cyanobacteria utilizes all available nitrogen present in the soil as organic and inorganic salts besides the elemental nitrogen. In addition, cyanobacteria can grow well in ammonia based commercial fertilizers. The cyanobacterial cultures grown in ammonium sulphate showed better growth rate than the cultures grown in urea. The cyanobacteria can use organic nitrogen to fulfil their nitrogen requirements but at the same time it can effectively assimilate the inorganic fertilizers such as urea and ammonium sulphate. In the present study, excretion of ammonia was greater in urea treated cyanobacterial cultures than ammonium sulphate treated cultures. There are reports that ammonium present in the growing medium does not allow the developments of heterocyst (Anand \& Karuppusamy, 1987) and it also inhibit the synthesis of nitrogenase in cultures that bear fully developed heterocyst. On the other hand, urea is a good nitrogen source for many cyanobacteria and its application will prevent various losses like ammonia volatilization, denitrification, run off and leaching. The chlorophyll-a and protein contents were comparably high in inorganic fertilizers treated samples than in control. It shows that the growth of W. Prolifica was stimulated by these inorganic fertilizers. The present study confirms that the cyanobacterium W. Prolifica can thrive well in presence of inorganic fertilizers and they are not degraded by the application of synthetic fertilizers. But, ammonia excretion was reduced in inorganic fertilizer treated cultures shows that these synthetic fertilizers affect the nitrogen fixation. Moreover, the nitrogen fixation rate will always reduce if excess nitrogen is present in the culture medium. The excess

Table 1: Effect of nitrogen sources on the protein and chlorophyll-a content after 28 days of inoculation

\begin{tabular}{lcccc}
\hline Treatments & \multicolumn{2}{c}{$\begin{array}{c}\text { Protein content in } \\
\mu \mathrm{g} \mathrm{ml}\end{array}$} & $\begin{array}{c}\text { Chlorophyll a content in } \\
\mu \mathrm{g} \mathrm{ml}^{-1}\end{array}$ \\
\hline Control & Urea & $\begin{array}{c}\text { Ammonium } \\
\text { sulphate }\end{array}$ & Urea & $\begin{array}{c}\text { Ammonium } \\
\text { sulphate }\end{array}$ \\
$1 \mathrm{ppm}$ & $94.71 \pm 0.11$ & $94.71 \pm 0.11$ & $8.94 \pm 0.03$ & $8.94 \pm 0.03$ \\
$5 \mathrm{ppm}$ & $99.37 \pm 0.05$ & $108.71 \pm 0.11$ & $8.84 \pm 0.05$ & $9.21 \pm 0.02$ \\
$10 \mathrm{ppm}$ & $110.81 \pm 0.11$ & $133.46 \pm 0.05$ & $9.35 \pm 0.05$ & $10.13 \pm 0.03$ \\
$20 \mathrm{ppm}$ & $115.43 \pm 0.11$ & $116.27 \pm 0.09$ & $9.64 \pm 0.08$ & $10.39 \pm 0.03$ \\
& $139.27 \pm 0.09$ & $141.11 \pm 0.08$ & $11.14 \pm 0.04$ & $12.11 \pm 0.03$ \\
\hline
\end{tabular}

(Values represent mean of three replicates \pm S.D.)

Table 2: Effect of nitrogen sources on ammonia excretion (n moles $\mathrm{ml}^{-1}$ )

\begin{tabular}{lcccc}
\hline Concentration & \multicolumn{4}{c}{ Days after inoculation } \\
\cline { 2 - 5 } & 7 & 14 & 21 & 28 \\
\hline Control & $30.12 \pm 0.15$ & $96.45 \pm 0.10$ & $78.37 \pm 0.08$ & $31.06 \pm 0.09$ \\
$1 \mathrm{ppm}$ urea & $22.38 \pm 0.08$ & $72.11 \pm 0.011$ & $49.24 \pm 0.05$ & $26.72 \pm 0.06$ \\
$5 \mathrm{ppm}$ urea & $18.78 \pm 0.06$ & $54.67 \pm 0.08$ & $36.44 \pm 0.08$ & $17.19 \pm 0.11$ \\
$10 \mathrm{ppm}$ urea & $15.34 \pm 0.10$ & $45.47 \pm 0.05$ & $21.33 \pm 0.07$ & $14.41 \pm 0.10$ \\
$20 \mathrm{ppm}$ urea & $13.22 \pm 0.09$ & $19.83 \pm 0.06$ & $15.72 \pm 0.04$ & $7.65 \pm 0.07$ \\
$1 \mathrm{ppm}\left(\mathrm{NH}_{4}\right)$ & $19.37 \pm 0.08$ & $54.32 \pm 0.09$ & $36.78 \pm 0.07$ & $18.91 \pm 0.06$ \\
${ }_{2} \mathrm{SO}_{4}$ & & & & \\
$5 \mathrm{ppm}\left(\mathrm{NH}_{4}\right)$ & $16.71 \pm 0.10$ & $25.36 \pm 0.11$ & $23.11 \pm 0.06$ & $17.03 \pm 0.10$ \\
${ }_{2} \mathrm{SO}_{4}$ & & & & \\
$10 \mathrm{ppm}\left(\mathrm{NH}_{4}\right)$ & $14.09 \pm 0.09$ & $20.31 \pm 0.07$ & $16.12 \pm 0.05$ & $11.23 \pm 0.13$ \\
$\mathrm{SO}_{4}$ & & & & \\
$20 \mathrm{ppm}\left(\mathrm{NH}_{4}\right)$ & $12.93 \pm 0.12$ & $19.18 \pm 0.05$ & $14.36 \pm 0.09$ & $10.24 \pm 0.10$ \\
$\mathrm{SO}_{4}$ & & & & \\
\hline
\end{tabular}

(Values represent mean of three replicates \pm S.D.) 
nitrogen also reduced the frequency of production of heterocyst which in turn affects the nitrogen fixating potential of this microorganism. So it is recommendable to use smaller amount of inorganic nitrogenous fertilizers in paddy fields along with the cyanobacterial biofertilizers for getting better yield from paddy. Thus, W. Prolifica is a promising biofertilizer which can be effectively utilized for paddy cultivation along with inorganic fertilizers.

\section{ACKNOWELDGEMENTS}

The author thanks the Head, Department of Botany, University of Calicut for providing facilities to carry out this piece of work.

\section{REFERENCES}

Alam, S., Seth, R. K. \& Shukla, D. N. (2014). Role of blue green algae in paddy crop. European Journal of Experimental Biology, 4, 24-28.

Anand, N. (1990). Responses of blue-green algae to certain common fertilizers. In: Proc. of Natl. Symp. on Cyanobacterial Nitrogen Fixation, New Delhi.

Anand, N., \& Karuppusamy, A. (1987). Growth of nitrogen fixing and non-nitrogen fixing blue-green algae in presence of some common fertilizers. Phykos, 26, 22-26.

Anand, N., \& Parameswaran, P. (1990). Salinity responses of a unicellular blue-green alga (Cyanobacterium) Chroococcus minor. Seaweed Research and Utilization, 13, 23-27.

Bottomley, P. J., \& Stewart, W. D. (1976). ATP pools and transientss in the bluegreen alga, Anabaena cylindrica. Archives of Microbiology, 108(3), 249-258. https://doi.org/10.1007/BF00454849

Halder, N. (2015). Recollections and taxo-ecological studies of Coleochaete scutata Bréb., Coleochaete pseudosoluta Gauthier-Lièvre and Coleochaete conchata Möb., West Bengal, India. Nepalese Journal of Biosciences, 5, 21-25.

Halder, N. (2016). Chemical composition and antibacterial activity of Lyngbya major Menegh. ex Gomont. Applied Science Reports, 13(1), 25-28.

Hall, D. O., Markov, S. A., Watanabe, Y., \& Rao, K. K. (1995). The potential applications of cyanobacterial photosynthesis for clean technologies. Photosynthesis Research, 46, 159-167, http://doi.10.1007/ BF00020426

Karthikeyan, N., Prasanna, R., Sood, A., Jaiswal, P., Nayak, S., \& Kaushik, B. D. (2009). Physiological characterization and electron microscopic investigation of cyanobacteria associated with wheat rhizosphere. Folia Microbiologica, 54(1), 43-51. https://doi. org/10.1007/s12223-009-0007-8

Kaushik, B. D. (1987). Blue-green algae: Their role in Indian Agricultrue. In Crop Productivity. H. C. Srivastava, S. Bhaskaran, \& K. K. G. Menon
(Eds.). New Delhi: Oxford and IBH Publ. Co., Pvt. Ltd.

Kaushik, B. D. (2001). Cyanobacterial biofertilizer technology. In National workshop on recent developments in biofertilizers for rice based cropping system (pp. 30-35). S. Kannaiyan, K. Govindarajan \& K. Kumar (Eds.). Coimbatore, India: Tamil Nadu Agricultural University.

Lowry, O. H., Rosenbrough, N. J., Farr, A. L., \& Randall, R. J. (1951). Protein measurement with Folin-Phenol reagent. Journal of Biological Chemistry, 193; 265-275.

Malik, F. R., Ahmed, S., \& Rizki, Y. M. (2001). Utilization of lignocellulosic waste for the preparation of nitrogenous biofertilizer. Pakistan Journal of Biological Sciences, 4, 1217-1220.

Parsons, T. R., \& Strickland, J. D. H. (1965). Particulate organic matter. III. I. Pigment analysis III. I.I. Determination of phytoplankton pigments. Journal of the Fisheries Research Board of Canada, 18, 117-127.

Paumann, M., Regelsberger, G., Obinger, C., \& Peschek, G. A. (2005). The bioenergetic role of dioxygen and the terminal oxidase(s) in cyanobacteria. Biochimica et Biophysica Acta-Bioenergetics, 1707, 231-253. https://doi.org/10.1016/j.bbabio.2004.12.007

Radhakrishnan, T. M., \& Venkitaraman, B. (2005). Effect of cyanobacteria on growth and yield of rice varieties in konaseema paddy fields-A delta regiona of East Goda Vaw District (Andhra Pradesh). Asian Journal of Microbiology Biotechnology and Environmental Sciences, 7, 823-830.

Rippka, R., Deruelles, J., Waterbury, J.B., Herdman, M. \& Stanier, R.Y. (1979). Generic assignments, strain histories and properties of pure cultures of cyanobacteria. Microbiology, 111, 1-61. https://doi. org/10.1099/00221287-111-1-1

Roger, P. A., Kulasooriya, S.A., Tirol, A. C. \& Craswell, E. T. (1980). Deep placement method of nitrogen fertilizer application compatible with algal nitrogen fixation in wetland rice soils. Plant and Soil, 57, $137-$ 142. https://doi.org/10.1007/BF02139650

Roger, P. A., \& Reynaud, P. A. (1979). Ecology of blue-green algae in paddy fields. In Nitrogen and Rice (pp. 289-309). Los Banos, Philippines: International Rice Research Institute.

Sao, S., \& Samual, K. (2018). Study of cyanobacteria as biofertilizer from the rice field. World Journal of Pharmaceutical Research, 4, 1696-1706.

Saxena, S., Singh, B. V., Tiwari, S. \& Dhar, D. W. (2007). Physiological characterization of cyanobacterial isolates from Orissa and West Bengal. Indian Journal of Plant Physiology, 12, 181-185.

Singh, P. K. (1981). Use of Azolla and blue-green algae in rice cultivation in India. In Associaitve Nitrogen Fixation (pp. 183-195). P. B., Vose, \& A. P. Ruschel (Eds.). Boca Raton, Florida: CRC Press.

Singh, R., Parihar, P., Singh, M., Bajguz, A., Kumar, J. \& Singh, S. (2017) Uncovering potential applications of cyanobacteria and algal metabolites in biology, agriculture and medicine: current status and future prospects. Frontiers in Microbiology, 8, 515. https://doi. org/10.3389/fmicb.2017.00515

Solorzano, L., (1969). Determination of ammonia in natural waters by the phenol hypochlorite method. Limnology and Oceanography, 14, 799-801. https://doi.org/10.4319/lo.1969.14.5.0799

Wilson, L. T. (2006). Cyanobacteria: A potential nitrogen source in rice fields. Texas Rice, 6, 9-10. 